\title{
Compliance of hand hygiene of healthcare workers in emergency care unit in a private tertiary hospital in São Paulo.
}

\author{
EA Tito*, J Kawagoe, P Gonçalves \\ From 3rd International Conference on Prevention and Infection Control (ICPIC 2015) \\ Geneva, Switzerland. 16-19 June 2015
}

\section{Background}

The objective of this study was to assess the compliance of hand hygiene $(\mathrm{HH})$ of healthcare workers (HCWs) in emergency care unit in a private tertiary hospital in São Paulo.

\section{Methods}

An observational study was conducted on the compliance of $\mathrm{HH}$ for the five World Health Organization (WHO) indications. HCWs were observed during routine patient care in day shift. The authors also measured the technique of $\mathrm{HH}$ through hand washing or hand hygiene with alcohol-based disinfectant. An observational study was performed before and after intervention. This intervention did training with the multidisciplinary team and communication (posters, email, phone and vídeo). The video was done with the healthcare workers in emergency care unit.

\section{Results}

A total of $530 \mathrm{HH}$ opportunities were identified during the observation period. Overal compliance before intervention (BI) was $56 \%$ and after intervention (AI) $72,4 \%$ $(\mathrm{P}<0.05)$. Compliance before and after intervention: nurses $(52,1 \%$ and $68.3 \%)[\mathrm{p}<0.05]$ and doctors $(59 \%$ and 75\%) $[\mathrm{p}<0.05]$.

\section{Conclusion}

Adherence to hand hygiene practice and use of alcoholbased disinfectant of the doctor was high compared with the literature. The main point was the participation of physicians in the intervention.

Hospital Israelita Albert Einstein, São Paulo, Brazil

\section{Disclosure of interest}

None declared.

Published: 16 June 2015

doi:10.1186/2047-2994-4-S1-P158

Cite this article as: Tito et al:: Compliance of hand hygiene of healthcare workers in emergency care unit in a private tertiary hospital in São Paulo.. Antimicrobial Resistance and Infection Control 2015 4(Suppl 1):P158.
Submit your next manuscript to BioMed Central and take full advantage of:

- Convenient online submission

- Thorough peer review

- No space constraints or color figure charges

- Immediate publication on acceptance

- Inclusion in PubMed, CAS, Scopus and Google Scholar

- Research which is freely available for redistribution

Submit your manuscript at www.biomedcentral.com/submit
C Biomed Central 